\title{
小児声門下狭窄症の手術的治療
}

\author{
*円谷 英一, 石橋 康, 松井 道夫 \\ **小河原 昇, 鯨井 和朗, 沢木 修二
}

\section{Surgical Correction of Subglottic Stenosis in Children}

\author{
Eiichi Tsumuraya, M.D., Yasushi Ishibashi, M.D. and Michio Matsui, M.D. \\ Department of Otolaryngology, Kanagawa Children's Medical Center, Yokohama
Noboru Ogahara, M.D., Kazuro Kujirai, M.D. and Shuji Sawaki, M.D.
Department of Otolaryngology, School of Medicine, Yokohama City
University, Yokohama

Two cases with congenital subglottic stenosis and four cases with acquired subglottic stenosis in children were treated at the authors' clinic during the past 10 years (1970-1979).

In the present paper, treatment of these cases is discussed. In five cases decannulation was successful.

After tracheostomy, the granulation tissue of the subglottic area was resected using the surgical microscope. A tracheal T-tube was set in place via tracheostoma. After six weeks of tracheal T-tube insertion, a tracheal cannula was used for four weeks prior to the closure of the stoma. Systemic administration of antibiotics and steroids and local administration of steroids were essential in treating these cases.

We believe that subglottic stenosis should be corrected surgically, even in small children.

\section{はじめに}

医療の進歩に伴い, とくに循環器系を中心と して，積極的な治療が行われる症例がふえてい る。このため，術後長期にわたり，気管内插管 を行ったり, 補助呼吸を必要とする症例も多く 尔った。この気管内捚管の合併症として，肉芽 形成，声門下狭窄，反回神経麻痺などの報告が 増加している。原因面からの予防手段として, 挿管チューブの形状，材質の改良，消毒法の工 夫，呼吸管理法の改善などが行われているが， なお合併症の発生は予防しきれていない。

小児に抒ける声門下狭窄では，呼吸困難が強 度であれば気管切開を行い，その後は，ある程
度まで成長を待つといらのが一般的な治療方法 であった。しかし, 最近は, 積極的な治療を試 みた報告がふえている。それらは，単にブジー で拡張をはかるものから, 喉頭を截開して軟骨 などの移植を行うものまでいろいろあり，その 侵襲度は大いに異なる。小児においてはとく に, その精神発達の面からも発声のもたらす影 響は大きいと思われる。

われわれの施設でも, 以前は成長を待つ立場 であったが, 最近の 5 年ほどは, 以上の観点か ら積極的に手術的治療を試みている。そして, 6 症例について各種の方法を試みたので，その 結果を報告し, 病態に応じた治療方針のたて方 を中心に考察を加えてみよう。

\footnotetext{
*神奈川県立こども医療センター耳鼻咽喉科

$* *$ 横浜市立大学医学部耳鼻咽喉科
} 
表 1 症例 の をと

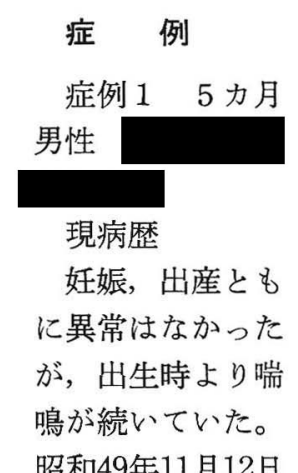

\begin{tabular}{|c|c|c|c|c|c|c|c|}
\hline & 年 齢 & 性別 & 原 因 & 挿管期間 & 療 & 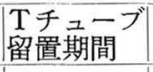 & $\begin{array}{l}\text { ステ } \\
\text { ロイド }\end{array}$ \\
\hline 1 & 5 力月 & 男 & 先天性 & - & 拡張術（ブジールング） & - & 全 身 \\
\hline 2 & $\begin{array}{l}6 \text { 歲 } \\
2 \text { 力贻 }\end{array}$ & $\prime \prime$ & 捅管後 & 9 日間 & $\begin{array}{l}\text { LMS 下の肉芽除去 } \\
\text { Tチューブ留置 }\end{array}$ & 40 日 間 & 11 \\
\hline 3 & $\begin{array}{l}4 \text { 歳 } \\
2 \text { 力罂 }\end{array}$ & 'l & $\prime \prime$ & 24日間 & "I & 50 日 間 & 11 \\
\hline 4 & 2 力月 & $\prime \prime$ & $\prime \prime$ & 60日間 & $\sqrt{1-5}$ & 56 日 間 & 全身・於 \\
\hline 5 & 7 力月 & $\prime \prime$ & $\prime \prime$ & 50 日間 & $\begin{array}{l}\text { 1. 喉頭形成術 } \\
\text { 2. LMS 下の肉芽除去, } \\
\text { Tチューブ留置 }\end{array}$ & 56 日 間 & "1 \\
\hline 6 & $\begin{array}{l}3 \text { 歳 } \\
10 \text { 月 }\end{array}$ & $\prime \prime$ & 先天性 & - & $\begin{array}{l}\text { LMS 下の肉芽除去・T } \\
\text { チューブ留置 }\end{array}$ & 41 日 間 & $\prime \prime$ \\
\hline
\end{tabular}

より, 上気道感染のため呼吸困難となり, チア ノーゼも出現した。このため当センターへ紹介 された。喉頭ファイバースコープにて, 声門直 下の粘膜肥厚, とくに輪状軟骨前壁部の肥厚が 認められた。声門下は約 $2.5 \mathrm{~mm}$ 径しかあいて いなかった。ほかに左副耳, 左停留音丸, 真性 包茎も合併していた。

治療

気管開空術の後，ステロイドの投与を続けた ところ, 成長のためもあり, 徐々に狭窄症状は 軽快してきた。約半年後の昭和50年 5 月 22 日よ り, 週 1 回食道ブジーによる拡張術を開始し た。6月19日より輪状軟骨が視野に入ってきた ので，同部の電気凝固を行った。同年 7 月ま で, 前後 9 回にわたり拡張術を行った結果, 狭 窄部分は $6 \mathrm{~mm}$ 径まで拡大された。しかし，そ の後心因反応がおこったため, 容易に気管カニ ニーレを抜くことはできなかった。そこで，精 神科にて加療し, 昭和51年 2 月 2 日気管カニ二 ーレの抜去に成功した。その後現在まで, 新し い肉芽の発生もみられず経過は順調である。

\section{症例 26 歳 2 力月 男性}

\section{現病歷}

妊娠, 出産ともに異常はなかったが, 生後, 口唇, 爪床のチアノーゼがとれないため, 昭和 47 年 10 月 6 日当センター循環器科に入院した。 心血管撮影にて大血管転位症の診断をうけた。 昭和53年 11 月 7 日, 大血管転位根治マスタード 術を行った。その後11月16日まで，9日閒経鼻 挿管をつゔけていた。抜管後しばらくは異常は なかったが，12月1日になり呼吸困難をきた

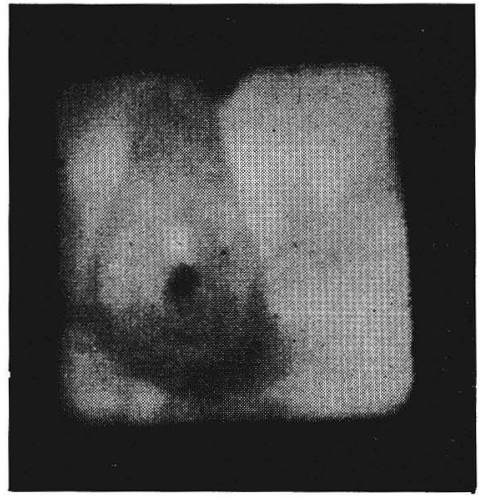

写真 1 症例 2 術前の内視鏡所見。

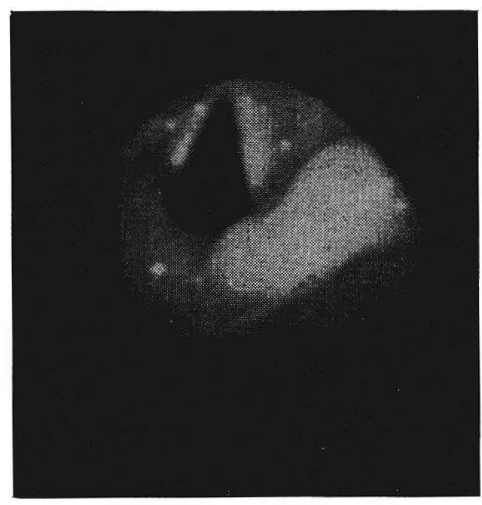

写真 2 症例 2 術後の内視鏡所見。

し，耳鼻科へ併診となった。ただちに喉頭ファ イバースコープにて, 全周性の声門下狭窄を確 認した。

治療

抗生物質とステロイドの投与により，呼吸困 難は軽快した。しかし, その後の1カ月間にさ らに 2 回呼吸困難をおこし， 2 度とも同様の投 
薬にて症状はおさまった。昭和54年 1 月 11 日， 気管開密術を行い，つづいて，LMS (laryngo micro surgery）で肉芽を除去し，気管内に 8

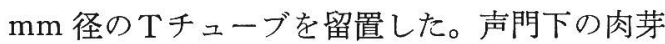
は膜様であり，中央に約 $2 \mathrm{~mm}$ 径の穴があいて いるのみであった（写真 1 )。1月25日 再びL MS で観察すると, 声門直下の左側に白くやわ らかい，広基性の肉芽が認められた。そこで再

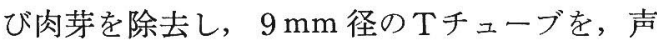
門上までつき出すようにして插入した。3 月 8 日 Tチューブを抜去し， $7 \mathrm{~mm}$ 径の気管カニュ ーレを挿入した。各操作後 $1 \sim 2$ 週間はステロ イドの投与を行い，抗生物質は全期間にわたっ て投与した。3 月28日の喉頭直達鏡の所見で は，前連合部にわずかに膜様のものが残るのみ であった（写真 2 )。そこで，カニューレを抜 去し，テープにて気管孔を閉鎖した。3月31日 退院し, その後は呼吸困難の再発もなく, 経過 は順調である。

\section{症例 34 歳 2 力月 男性}

\section{現病歷}

妊娠, 出産ともに異常なく, 生後の成長も正 常であった。昭和 49 年 11 月 10 日, 腸重積のため 某病院にて緊急手術を行った。翌日より高熱と なり，呼吸困難のため ICU にて経鼻挿管を 24 日間続けた。昭和53年 2 月 21 日, 嗄声, 喘鳴, 鎖骨上窝の陥凹などを主訴として当科へ来院し た。喉頭ファイバースコープにて, 声門下に全 周性の肉芽を確認できた。

\section{治療}

抗生物質とステロイドの投与により, 呼吸困 難症状が軽快したため, 保存的治療をつづけて いた。しかし, 昭和53年10月頃より再び, 発 熱, 呼吸困難をくりかえすようになった。昭和 54 年 1 月 11 日, LMS 下に声門下の 肉芽を除去 し， $8 \mathrm{~mm}$ 径の Tチューブを留置した。声門下 の肉芽は，声帯より約 $1 \mathrm{~cm}$ 下方で，中央に丸 く穴のあいた厚さ約 $2 \mathrm{~mm}$ の膜様物であった (写真 3 )。その後, 抗生物質とステロイドの投

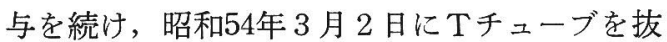
去し， $8 \mathrm{~mm}$ 径のカニューレに交換した。その 後, 時々気管孔をふさぎ，様子をみていたが，

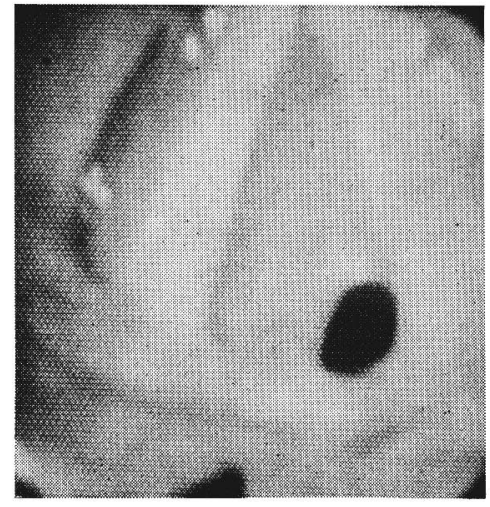

写真 3 症例 3 術前の内視鏡所見。

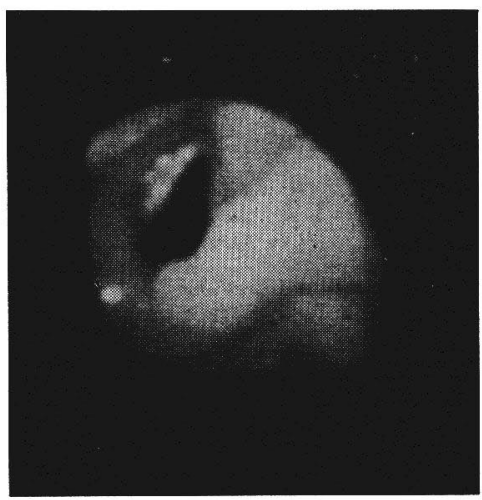

写真 4 症例 3 術後の内視鏡所見。

呼吸困難もおきないため，3 月28日カニューレ 䒚抜去し，気管孔をテープにて閉鎖した。この 時の喉頭所見では声門下の膜様物は全くなくな っていた（写真 4)。3 月30日退院しその後呼 吸困難の再発もなく経過澒調である。

\section{症例 4 力月 男性}

現病歷

40 週の満期産ながら，出生時体重は $2000 \mathrm{~g}$ で あった。特発性呼吸窮迫症（肺硝子膜症）のた め, 約 2 力月間気管内挿管を続けた。抜管寸る と呼吸困難をきたすため当センターへ紹介され た。昭和 52 年 10 月 5 日, 直接喉頭鏡にて声門下 の肉芽を確認した。狭窄は，輪状軟骨の高さで 全周にわたる厚さ約 $5 \mathrm{~mm}$ の膜様物によるもの であった。また，幽門狭窄もみとめられた。

治療

昭和52年 10 月 8 日，気管開空術を行い，気管 
内に挿管していたチューブを抜去した。10月11 日，幽門筋切開術を行った。12月23日，LMS にて声門下の肉芽を除去した。ステントは用い なかった。

その後再び同部位に肉芽の増生がみられたの で, 昭和53年 3 月 30 日, 喉頭截開術, 喉頭気管 形成術を行い，ステントを留置した。

5 月 23 日，ステントを除去したが，その後再 び肉芽が充満してしまった。昭和53年 9 月 26 日, LMS 下に再び肉芽を除去し, $7 \mathrm{~mm}$ 径の Tチューブを挿入した。昭和 54 年 1 月 16 日， $\mathrm{T}$ チューブを抜去してみたが，気管孔をとじる と, 著明な呼吸困難がおこるため，2 日後再び Tチューブを挿入した。同月 30 日にはさらに チューブを $8 \mathrm{~mm}$ 径のものに交換した。6 月 28 日， LMS 下にTチューブを抜いて声門下を観 察したところ，狭窄はまったくなかった。しか し, 1 カ月後再び肉芽の発生がみられ, 8 月 16

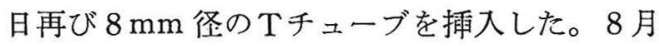
27日，Tチューブを挿入したまま退院し，外来 にて経過をみていた。10月 2 日，Tチューブを 抜去し，カニューレにかえたが，その後徐々に 狭窄が再び生じてきた。昭和55年 1 月 9 日再入 院した。LMSによる喉頭の所見は，声門下約 $2 \mathrm{~mm}$ ぐらいのところから下に約 $1 \mathrm{~cm}$ の厚み をもった狭窄ができていた。中央には径約 3 $\mathrm{mm}$ の穴があいていた。

そこで, 喉頭を截開し, 輪状軟骨から第 3 気 管輪までのあいだを前方開大し， $8 \mathrm{~mm}$ 径の $\mathrm{T}$ チューブをおいたうえに肋軟骨を移植した。現 在の予定では，3カ月後にTチューブを抜去す る予定でいる。この例ではとくに若かったこと と, 狭窄部の厚みのあったこととが, 治療に手 間どった原因と考えている。

\section{症例 57 力月 男性}

\section{現病歴}

妊娠, 出産ともに異常はなかったが, 生後 1 カ 月のとき心雑音を指摘された。昭和53年 3 月 1 日, 心血管撮影を行い, 心房中隔欠損症の診断 をうけた。4月18日, かぜをひき, 全身状態が 悪化したために経口にて気管内挿管を行った。 4 月23日にはバードレスピレーターを装着し た。全身状態が改善したため，5月 8 日と 5 月

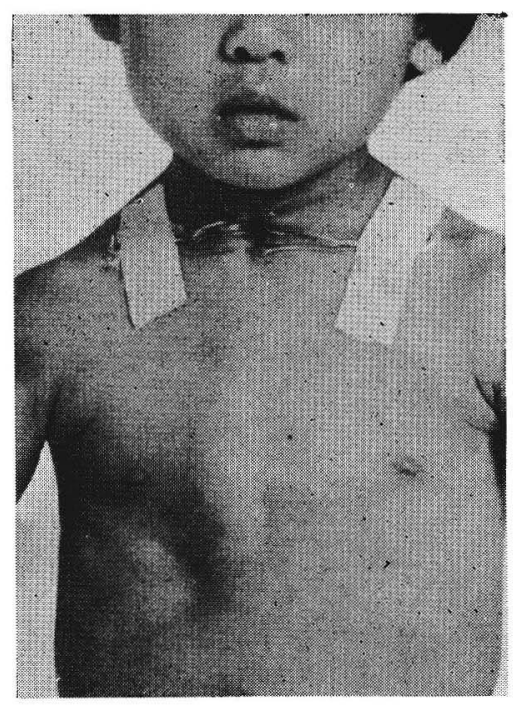

写真 5 症例 6 入院時著明な胸郭の陌 凹がみられた。

29日とに抜管を試みたが呼吸状態が悪化するた めにできなかった。6月 3 日，耳鼻科を受診 し, 喉頭ファイバースコープにて声門下の肉芽 が確認された。肉芽は声門直下にあり, 後端に 径約 $2 \mathrm{~mm}$ の隙閒を残すのみであった。 治療

6 月 13 日 気管開空術を行い, LMS 下に肉芽 を除去し、デササメサゾン $2 \mathrm{mg}$ を局注し, 径 $7 \mathrm{~mm}$ の $\mathrm{T}$ チーブを㨂入した。その後, 3 回, LMS 下の操作を試みたが, 全身状態が悪化し たため十分できず，現在も Tチューブを挿入し たままで, 成長を待っている。

\section{症例 62 歳 5 力月 男性}

\section{現病歴}

妊娠, 出産には異常はなかったが, 出生時よ り喘鳴があった。昭和53年 4 月 15 日, 当科に受 診し, 先天性声門下狭窄症の診断をうけた。そ の後とくに症状もみられなかったが，昭和54年 になってから，1月と 6 月とに上気道感染のた めの呼吸困難がおこった。その都度, 抗生物質 とステロイドの投与により呼吸困難は改善し た。 7 月 7 日, 手術的治療を目的とし, 当セン ターへ入院した。入院時, 長期にわたる呼吸困 難のための胸郭の変形がみられた(写真 5 )。 7 
月 7 日，気管開空術を行い， 7 月 12 日には， LMS 下に肉芽を除去してケナコルト $40 \mathrm{mg}$ を 局注し, 径 $7 \mathrm{~mm}$ の $\mathrm{T}$ チューブを留置した。肉 芽は声門直下より $2 \sim 3 \mathrm{~mm}$ の厚さで前方を中 心に増生しており, 気管腔は後部 $1 / 3$ ぐらいあい ていた。Tチューブの上端より再び肉芽の増殖 がみられたので，7月26日再び LMS を行い， 肉芽を除去し，ケナコルトの局注を行い，声門 上までとどく Tチューブに変更した（写真 6 ,

7 )。9 月 5 日， $\mathrm{T}$ チューブを抜去し，カニュ ーレを装着した。

9 月27日，LMS にて声門下を観察したとこ ろ，声門下の肉芽はなかったが，前連合部よ りポリープ様のものが生じていたので切除し, ケナコルトの局注を行った。10月15日, 再び LMS 下に観察し, 再狭窄のないことを確認し たのでカニューレを抜去し, 気管孔をテープで 閉鎖した。その後現在まで再発はなく, 経過は 順調である。

\section{考 按}

小児の声門下狭窄症の場合，大人とは異な り, 全体に小さいため手術的操作が加えにく 、。また，肉芽もおこりやすく，患者自身ある いは家族の治療に対する理解も少ないため, 保 存的治療中にカニューレのトラブルなどで死亡 する率も高いといわれている。さらに，気管内 插管後におこったものの場合は, 重大な基礎疾 患のあることが多く, 積極的な処置はとかく敬 遠され，消極的な治療となりやすい。しかし，小 児の場合その発声機能の有無法, 精神発達上重 大な影響をおよぽすことは容易に予想される。 また, 症例 6 のように胸郭の発達その他の全身 的影響も見逃すことはできない。

小児の声門下狭窄症の原因としては, 第 1 に 気管内挿管の普及があ げられる。気管内挿管 が，気管切開より安全であり容易な手技である ため広く普及したこと, また, 全身麻酔も気管 内捚管によって行うのが一般的となり, 総挿管 回数の増加したこととが理由であろら。第 2 の 理由としては, 手術そのものが高度化し, とく に心臟の手術の普及に伴い, 術後呼吸管理の行 われることが多くなったことがある。 Strong ${ }^{1}$ によれば補助呼吸の行われた場合その $5 \sim 6 \%$

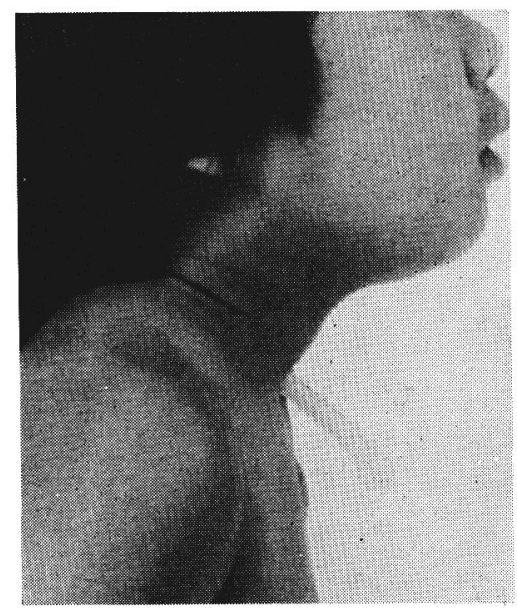

写真 6 症例 6 Tチューブ装着中の写真。 栓をしても呼吸ができる。

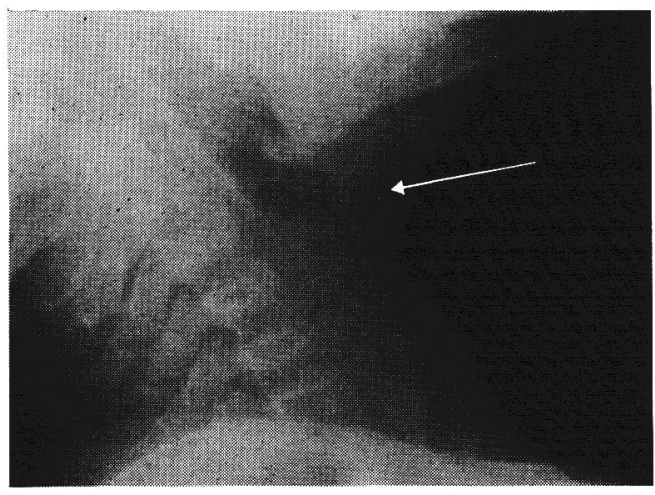

写真 7 症例 6 Tチューブ装着中の側 面レントゲン写真。声門上までT チューブの先端がでている。

表 2 小児声門下狭窄症の治療方法

\begin{tabular}{|c|c|}
\hline 保存的治療 & $\begin{array}{l}\text { 1. 成長を待つ。 } \\
2 . \text { ステロイド, 抗生物質などの薬 } \\
\text { 物投与。 }\end{array}$ \\
\hline 手術的治療 & $\begin{array}{ll}\text { 1. 拉張術 (ブジールング)。 } \\
\text { 2. 内視鏡下の肉芽除去, ステント } \\
\text { 留值。 } \\
\text { 3. 喉頭截開による喉頭形成術。 }\end{array}$ \\
\hline
\end{tabular}

に声門下狭窄が発生するといら。これを予防す るためには, 今後, 気管内チューブの大きさ, 形状, 材質, 固定方法などについて, より一層 の改良が加えられなければならない。 
声門下狭窄症の治療としてわれ われの臨床ではこれまで, 成長を 待つのが基本方針であった。しか し，聴力障害児と同様の情緒不安 定が，声門下狭窄のため気管カニ ューレを装着している子供にもみ られる。こうした心理的な面から も早期に発声を可能とさせる治療 が望ましいと考えるようになっ た。文献上でも, ある程度まで 成長を待つという Holinger²), $\mathrm{Krajina}^{3)}$ らの意見と，気管切開 を行っている場合の気道トラブル の多さから早期治療をすすめる

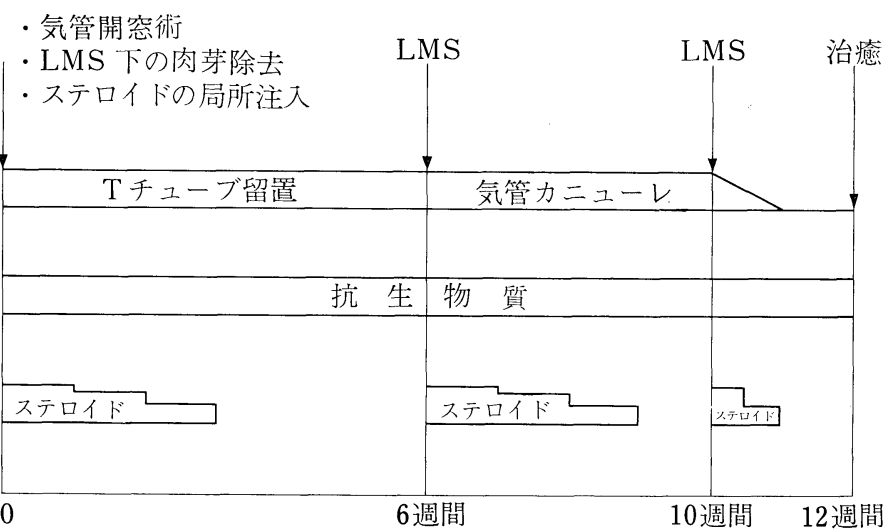

図 1 小品声門下狭窄症の治療計画 (Time schedule)
Fearon $^{4)}$, Cotton $^{5)}$ らの意見とがある。

手術的治療方法としては, 気管開空術を行っ た上で拡張術を併用する方法, 肉芽を除去した のち，ステントを挿入する方法，および，各種 の喉頭形成術がある（表 2 ）。だが当然のこと ながら全ての症例に画一的にあてはまる方法は なく，各々の症例にあわせて一番適切な方法を 考えるべきである。

ブジーによる拡張術は，侵襲の度合いも少な く, 1 回毎の手間もかからない。症例 1 のよう に，狭窄部のうすい場合は，ステロイド，抗生 剂と併用しながら行うのがよいと思う。しか し, 反面, 何回も行うことが必要であり, 狭窄 を完全にとることが難しいし，効果が不確実で あるといら欠点もある。

この点を改良するために，拡張あるいは肉芽 を除去したあとにステントを留置する方法が考 えられた。ステントの形状としては, Montgo-

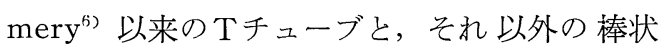
のチューブとに大きくわけられる。両者には決 定的な優劣はないが，われわれはTチューブの 方が優れると考えている。その理由は，固定が しやすいこと，插入抜去が容易なこと，気道も 自然に近く，乙かも自然発声が可能なことなど である。短所としては，上下にあいているため に，誤嬩しやすいことがあげられるが，写真 7 のように声門上まで入れておいても，看護上よ

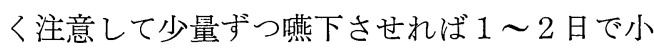
児はなれるものである。われわれは，このため の與下性肺炎を併発した症例を経験していな
い。ほかには, 円柱状をしているために, 抜去 後嗄声があるが，それも徐々に軽快する。 ステントを留置する期間についてはいろいろ な意見がある。気管の喘々吻合をした場合のよ らに 3 週間で十分だとするものから，3 カ月以 上の長期間留置す心゙きであるという意見までわ かれている。しかし, 動物実験では約 5 週間で 粘膜の修復はおわるとされており, われわれ は， 6 週間前後を標準としている。長期間おけ ばそれだけ確実ではあるが，手術の目的である 短期治療に相反することになる。われわれの経 験では，肉芽を除去した部分にきちんと Tチュ 一ブがあたっていた場合は, これを除去した後 に再び狭窄する例は少なく, Tチェーブのきち んとあたっていなかった部分から肉芽が増殖

し, 再狭窄をきたす例が多かった。

喉頭を截開して声門下に達する喉頭形成術 は, 明視下に肉芽を除去できる点では一番完全 である。肉芽を除去したあとそこにステントを 留置するのが一般的であるが，拡大された管腔 に対応する外壁として, 耳介軟骨, 肋軟骨, 舌 骨，甲状軟骨の一部などを使うこともある。そ れぞれによい結果が報告されているが，このよ うに小巟にとって侵襲の大きい方法をとるの は，内視鏡的に操作できないほど厚みがあり， かつ範囲の広い狭窄の場合に限られる。

手術的治療と併用する薬剤としては, 一般的 には，ステロイドの局所注入が有効である。ま た同薬剤の全身投与も各種の手術後一定期間必 要であると考えている。抗生物質の投与は, 局 
所における感染を抑制し, 肉芽の発生をおさえ る作用があり，その上，與下性肺炎の予防の面 からも欠かすことはできない。

以上よりわれわれの考える治療方針を模式 的に示せば図 1 のらになる。まず気管開空術 を行い，ただちにLMSにて声門下の肉芽を除 去し狭窄をとる。その上でステロイド（トリア ムシノロン $40 \sim 80 \mathrm{mg}$ ） を局所注入する。つい で気管孔より長めのTチューブを挿入し，声門 上まで出ていることを確認する。これを 6 週間 留置し，LMS 下にTチューブを抜去し，声門 下狭窄のないことを確認する。も乙肉芽があれ ぼ再び肉芽を除去し，さらに太目の Tチューブ を入れ 6 週間以上待つ。肉芽がなければステロ イドの局注のみを行い, 気管カニューレに变更 する。カニューレは毎日交換し時々気管孔をテ ープでふさいで呼吸困難がおこらないかを試し てみる。

4 週間後, 再び LMS 下に声門下を観察, 狭窄 の有無をたしかめる。狭窄のない場合は, カニ ユーレを抜去し，気管孔をテープでふさぐ。こ の部分の美容的形成術は $5 \sim 6$ 歳になってから 行う。それぞれの手術的操作のあとは, プレド ニゾロンを体重 $1 \mathrm{~kg}$ あたり $1 \mathrm{mg}$ の日量で開始 し， 3 週間で漸減させる。抗生物質は全期間投 与を続ける。以上の方法により 2 〜歳以上な らば，多くの場合治療は成功する。不幸にして この方法で十分な気道が得られないときは，喉 頭形成術を併用しなければならない。すなわ ち, 全ての症例にはじめから喉頭形成術を適用 する必要はないと思う。

\section{まとめ}

6 例の小児声門下狭窄症の患者に積極的な治 療を行い，5例に成功し，1例経過観察中であ る。その結果につき考察をくわえ，つぎのよう な結論を得た。

1. 気管切開を必要とするほど狭窄がひどい 場合は，年齢が低くても手術的治療を試みるべ きである。

2. 手術的治療としては，気管開空術を行い LMS 下に肉芽を除去し，Tチューブを留置す るのが簡単で, かつ確実である。喉頭形成術 は，以上の方法で失敗した例にのみ行う。
3. 局所へのステロイド注入と, 全身へのス テロイド，抗生物質の投与は必要である。

（本論文の要旨は，1979年11月の第31回日本気管 食道科学会にて報告した。)

\section{文 献}

1) Strong, R.M. and Passy, V.: Endotracheal intubation. Complications in neonates. Arch. Otolaryngol., $103:$ 329-335, 1977.

2 ) Holinger, P.H., Kuntnick, S.L., Schild, J.A. and Holinger, L.D.: Subglottic stenosis in infants and children. Ann. Otol., 85 : 591-599, 1976.

3 ) Krajina, Z. and Vecerina, S.: Chronic stenosis of the larynx in children. J. Laryngol. Otol., $93: 81-88,1979$.

4) Fearon, B. and Cotton, R.: Surgical correction of subglottic stenosis of the larynx in infants and children. Progress report. Ann. Otol., 83: 428-431, 1974.

5 ) Cotton, R.: Management of subglottic stenosis in infancy and children. Ann. Otol., $87: 649$ 657, 1978.

6 ) Montgomery, W.W.: Silicone tracheal T-tube. Ann. Otol., 84 : 71-75, 1974.

7 ) Rabuzzi, D.D. and Reed, G.F.: Intrathoratic complication following tracheotomy in children. Laryngoscope, 81 : 939-946, 1971.

8 ) Waggoner, L.G., Belenky, W.M. and Clark, C.E.: Treatment of acquired subglottic stenosis. Ann. Otol., $82: 822-826,1973$.

9 ) Fearon, B. and Ellis, D.: The management of long term airway problems in infants and children. Ann. Otol., 80 : 669-677, 1971.

10) Parkin, J.L., Stevens, M.H. and Jung, A.L.: Acquired and congenital subglottic stenosis in the infant. Ann. Otol., $85: 573-581,1976$.

11) Jazbi, B., Goodwin, C., Tadkett, D. and Faulkner, S.: Idiopathic subglottic stenosis. Ann. Otol., 86 : 644-648, 1977.

12) Schofield, J.: Conservative treatment of subglottic stenosis of the larynx. Arch. Otolaryngol., $95: 457-460,1972$.

13) Duvall, A.J. and Bauer, W.: An endoscopically introducible T-tube for tracheal stenosis. Laryngoscope, 87 : 2031-2037, 1977.

14) Tonkin, J.P. and Harrison, G.A.: The surgical management of the laryngeal complications of prolonged intubation. Laryngoscope, $81: 297$ 307, 1971.

15) Goode, R.L. and Shinn, J.B.: Long term stenting in the treatment of subglottic stenosis. Ann. Otol., 86 : 795-798, 1977.

16) Gerwat, J. and Bryce, D.P.: The management of subglottic laryngeal stenosis by resection 
and direct anastomosis. Laryngoscope, $84: 940$ 957, 1974.

17) Crysdale, W.S. and Platt, L.J.: Division of posterior cricoid plate in young children with subglottic stenosis. Laryngcscope, 86:14511458, 1976.

18) Mulraney, T.J. and Miller, D.: Endolaryngeal cryosurgery. Arch. Otolaryngol., 102:226229, 1976.

19) Croff, C.B., Zub, K. and Borowiecki, B.: Therapy of iatrogenic subglottic stenosis. A steroid antibiotics regimen. Laryngoscope, 89 : 482-489, 1979.

20) Fearon, B., Crysdale, W.S. and Bird, R.: Subglottic stenosis of the larynx in the infant and child. Method of management. Ann. Otol., 87 : 645-648, 1978.

別刷請求： $=233$ 神奈川県横浜市南区六ッ川 神奈川県立こども医療センター耳鼻科 円谷 英一

（投稿受付 1980 年 3 月 5 日） 